\title{
Observation of Varroa destructor behavior in capped worker brood of Africanized honey bees
}

\author{
Rafael A. Calderón • Guisella Chaves • Luis A. Sánchez • \\ Rolando Calderón
}

Received: 9 March 2012/Accepted: 17 May 2012/Published online: 12 June 2012

(C) Springer Science+Business Media B.V. 2012

\begin{abstract}
The behavioral activity of Varroa destructor was observed using transparent cells. Mite oviposition started at $45.0 \pm 25.0 \mathrm{~h}$ post capping, followed by the next eggs laid at regular $27.3 \pm 2.0 \mathrm{~h}$ intervals. On the prepupa, mites were found to feed often and there was no preference for a specific segment as a feeding site. During the pupal stage the mite fed less often and almost always at the same point. Varroa showed a preference for defecation in the posterior part of the cell. A significant association was observed between the position of the feeding point in the pupa and the defecation site on the cell wall. Displacement behavior was observed in $71 \%$ of the infested bee larvae and a major change in the free space available for varroa in the cell occurred when the prepupa molted into a pupa.
\end{abstract}

Keywords Varroa destructor - Varroa mites - Africanized honey bees · Oviposition · Feeding $\cdot$ Fecal accumulation $\cdot$ Molting

\section{Introduction}

The mite Varroa destructor Anderson and Trueman (2000) (Mesostigmata: Varroidae) is a worldwide ectoparasite of honey bees with serious economic importance for beekeeping. The problem is most acute in regions with a temperate climate, which have bees of European origin (De Jong 1997). Severe mortality due to this mite has been reported in colonies of European honey bees (EHB) in many countries of Europe, Asia and North America (Bailey and Ball 1991; Mobus and Bruyn 1993). However, in tropical regions of

R. A. Calderón $(\bowtie) \cdot$ L. A. Sánchez

Programa Integrado de Patología Apícola, Centro de Investigaciones Apícolas Tropicales,

Universidad Nacional, Heredia, Costa Rica

e-mail: rcalder@una.ac.cr

G. Chaves · R. Calderón

Escuela de Ciencias Biológicas, Universidad Nacional, Heredia, Costa Rica

G. Chaves

Ministerio de Agricultura y Ganadería, Heredia, Costa Rica 
Brazil, where honey bees are Africanized the mite effect on the colonies appears to be reduced to the point where no control measures are necessary and no colony losses because of this mite seem to occur (De Jong 1997; Moretto 1997; Moretto and Leonidas 2001, 2003).

The female mite reproduces within the honey bee-sealed brood cell, which it invades just prior to it being capped. After cell capping the mite feeds on the developing bee and lays several eggs. About 60-70 h after the brood cell is sealed, the first egg is laid. They are laid one by one, usually on the cell wall at intervals of about $30 \mathrm{~h}$ (Martin 1994).

The first egg is generally male, and the rest female (Martin 1994). Mites go through the following instars: eggs-larva, ambulatory protonymph, immobile protonymph, ambulatory deutonymph, immobile deutonymph and adult (Martin 1994). The offspring feed at a site established by the mother mite on the bee brood, mature and mate within the cell (Donzé and Guerin 1994). The mature female mites leave the cell when the host bee emerges. Outside the cell (phoretic phase) the female mite lives attached to the adult bee where it feeds regularly on the bee's haemolymph by piercing the host membrane. Male do not survive outside the brood (Martin et al. 1997).

The worker brood cell would appear to provide a safe environment for mite reproduction, with its stable temperature and humidity, accessible food source, and absence of predators (Donzé and Guerin 1994). Nevertheless, the time available for mite reproduction is limited (varroa must reproduce within the duration of the capped brood, 12 days in worker brood) and the changes occasioned by the bee's development limit the space available for the foundress mite and its descendants. Furthermore, physiological characteristics of the honey bee larva or pupa might also afford some resistance to varroa mites. For example, mite reproductive rates might be lowered if there is reduced feeding activity on the larva or pupa by the foundress mites (Grandi-Hoffman et al. 2002) or offspring mortality due to bee's movement at pupation (movements of the molting bee pupa) can occur. Indeed, traits expressed by bee larva and pupa might be in part responsible for the lower fertility rates of mites in the worker brood of Africanized bees in Brazil, which show an increased tolerance to V. destructor (Ritter and De Jong 1984).

Because mite reproduction occurs within the sealed cell, the direct observation of varroa activity inside the cell is difficult. Due to reduced reproduction of varroa is regarded as the most important factor in tolerance of Africanized bees toward this parasite, an observation method using artificial cells was used to analyze the behavior of varroa mites in worker brood cells of AHB. So far few experiments under such well-defined conditions have been carried out with Africanized bees (Calderón et al. 2009). Observations on transparent cells in European bees demonstrate significant adaptations on behalf of varroa mites in parasitizing the developing bee inside the capped brood cells (Donzé and Guerin 1994, 1997; Donzé et al. 1998).

One approach to controlling varroa mites would be to select bees that suppress or delay mite reproduction. Low rate of reproduction has a negative influence on the rate of mite population growth (Martin and Medina 2004). In worker brood cells of AHB, a factor that limited varroa reproduction ability included brood cells with only a female offspring (Calderón et al. 2003; Correa-Marquez et al. 2003; Mondragon et al. 2006).

The absence of the male or premature death of the male offspring within the host cell before it is able to mate with its sisters leads to unfertilized adult female offspring emerging from the cell. Since only one male is produced per batch of eggs, its absence or death will result in all the female offspring being unmated and so unable to produce offspring although they do enter cells and attempt to reproduce (Donzé et al. 1996; Harris and Harbo 1999). The mortality suffered by the first (specifically the male protonymphs) 
mite offspring found in $\mathrm{AHB}$, is thought to contribute in part to the tolerance of the bees (Medina and Martin 1999).

We hypothesize that, due to the reduced number of viable female mite offspring found in worker brood cells of AHB, a considerable rate of male absence or male mortality should occur in worker brood cells. Therefore, the aim of the present study was to investigate $V$. destructor behavior, focusing on mite oviposition in worker brood cells of AHB colonies.

\section{Materials and methods}

The study was carried out at the Universidad Nacional, Heredia, Costa Rica $\left(10^{\circ} 01^{\prime} \mathrm{N}\right.$, $84^{\circ} 07^{\prime} \mathrm{W}$; $1,130 \mathrm{~m}$ altitude), from February to December 2008 using four Africanized colonies. An observation method using transparent polystyrol cells containing infested brood was used to analyze the behavior of varroa mites in worker brood. We set out to establish how the female succeeds in parasitizing the developing bee, feeds on the pupa and constructs a fecal accumulation site. A special attention was paid to mite oviposition. Five non-infested cells were also analyzed for larva and pupa development.

Artificial brood cells

In order to study varroa behavior in worker brood of AHB, artificial cells containing naturally reared brood, infested by a single mite were used for continuous observation. Cylindrical transparent polystyrol cells with internal dimensions of $5.1 \mathrm{~mm}$ diameter $\times 14 \mathrm{~mm}$ long for workers were used. The dimensions of the polystyrol cells are similar to those of natural ones and those cited in the literature for workers. These artificial cells were inserted into a brood comb and put into an experimental colony. The position of the artificial cells in the comb was recorded on transparent sheets. The cells were checked every day for oviposition. About 8 days after oviposition, the time of sealing of each cell was recorded at short intervals (approximately every $4 \mathrm{~h}$ ).

The infested cells were transferred to a laboratory incubator (water jacketed) maintained at $35{ }^{\circ} \mathrm{C}$ and $60.0 \% \mathrm{RH}$ (simulating hive conditions of temperature and humidity). Considering the importance of geotaxis in varroa (Donzé and Guerin 1994), the cells were placed in the natural position (pupa on its back) fixed to a piece of cardboard and turned only occasionally for observations.

Direct observations of the cells were made with a micro-camera connected to a timelapse VHS and recorded a minimum of 6 days $(144 \mathrm{~h})$ and a maximum of 7 days $(168 \mathrm{~h})$ (about 2 frames $\mathrm{s}^{-1}$ ). This system allowed direct observation of the cell, as well as recording of the varroa behavior. A red light source illuminated the cells. Only one artificial cell was recorded at a time.

Observations on brood cells

An ethogram was established and the following behavior was studied for varroa mites: mite oviposition, how the mite chooses a site for feeding, feeding frequency, hourly mean amount of feeding, and how varroa initiates and subsequently succeeds to build a fecal accumulation site. In addition, the molts of bee prepupa into a pupa and the displacement activity of the bee larva (prepupa) were recorded. 
Mite oviposition behavior was reported when the egg emerges from the genital opening, was sustained and stucked against the cell wall. A mite was considered to be feeding if it was immobile on the feeding site with the head region inclined and pushed against the cuticle of the bee brood, showing up and down movements in the anus region. Defecating behavior was reported when varroa abruptly stops, waggles its anus dorsoventrally and deposits the feces. To establish the position of the egg laying and fecal accumulation site, the artificial cell was divided in three sections (anterior, medium and posterior). The anterior section corresponded with the cell cap and the head of the pupa.

All the recorded pupae were analyzed for the position of the fecal accumulation site. In addition, natural infested pupae were also analyzed for the position of the feces. The molts of prepupa into a pupa was registered. The reaction of varroa to bee pupation was observed, specifically great attention was given to young instars such the disturbance of the first mite egg. Longitudinal displacements (displacement behavior) of the bee larva were registered when the larva turned around in the cell, from the bottom to the top.

After 7 days of observation (168 $\mathrm{h}$ after capping) the cells were opened to examine the contents. Bee pupae and mites were taken out, and mites (mature and immature stages) were identified and counted using a stereoscope microscope $(10 \times$ magnification). The bottom of the cell was also examined. In addition, the exuviae of the bee brood were removed and checked for mites. The mite condition was evaluated using the following parameters: general aspect, locomotion (walking), and appendage motion (legs, chelicerae).

Feeding site position on the pupa

A vital staining with trypan blue was used to detect the number and exact position of the mite-made (for feeding) integumental wounds on the pupal stage (Kanbar and Engels 2004a). Controls were incubated in dye-free ringer. All the recorded pupae were analyzed for the position of the wound. Furthermore, naturally infested pupae ( 7 days or more) were also analyzed for the position of the wound.

Time-activity analysis

For each observation, the total duration and the frequency of each behavior displayed on either the bee brood or the cell wall were calculated. We analyzed the section in the cell where the fecal accumulation was established and the location of the feeding site. A major change in the free space available for varroa mites occurs when the prepupa molts into a pupa. While molting, the mouthparts and other structures of the pupa emerge and extend backwards which may disturb the egg. Varroa is therefore confronted with quite dramatic changes to the available space due to metamorphosis - a factor which increases the risk of mite mortality (Donzé and Guerin 1994). For this reason, special attention was paid to the anterior part of the cell, where the first egg is usually positioned.

\section{Results}

Varroa mites behavior was recorded in 31 artificial worker size cells, but not all cells were used for analysis. In four cells, the mite was found dead and in one cell the bee larva showed European Foulbrood symptoms. 
Mite reproduction

Varroa fertility can be defined on the basis of whether a female lay an eggs or not. In this study, mite fertility was $30.8 \%(\mathrm{n}=26)$ (Table 1$)$, a lower percentage of mites reproduce in artificial worker brood. Most of the foundress mites that did not reproduced looked alive and healthy (i.e. exhibited locomotion and appendage motion). Because the activity in the cells were recorded for a maximum of 7 days (168 h after capping, not entire reproductive cycle), not viable female offspring was observed (under natural conditions the worker cell remains capped $120 \mathrm{~h}$ more).

\section{Mite oviposition}

Mite oviposition started at (mean \pm SD) $45.0 \pm 25.0 \mathrm{~h}(\mathrm{n}=7)$ post capping, followed by the next eggs laid at regular $27.3 \pm 2.0 \mathrm{~h}(\mathrm{n}=6)$ intervals (Fig. 1). As the egg emerged from the genital opening, varroa sustained it at the cell wall. After sustaining the egg for $15.3 \pm 4.2 \mathrm{~m}(\mathrm{n}=15)$ the mite left the site. The oviposition site for the first egg was mainly situated in the anterior part of the cell (close to the cell cap), meanwhile the rest of the eggs were located in the posterior part of the cell, usually close to fecal accumulation site.

After oviposition, the mobile protonymph hatched at $27.1 \pm 3.2 \mathrm{~h}(\mathrm{n}=9)$. This stage lasted $39.1 \pm 14.3 \mathrm{~h}(\mathrm{n}=5)$.

Molts of bee prepupa into a pupa

A major change in the free space available for varroa occurred when the bee prepupa molts into a pupa. Molting started at $56.2 \pm 12.4 \mathrm{~h}$ post capping $(\mathrm{n}=26)$. While molting, the mouthparts, antennae and legs of the pupa emerged and extended backwards.

Influence of the bee molting in the condition of the mite eggs

In this study, $70.0 \%$ of the fertile mother mites laid the first egg before bee pupation. The molting last $45.0 \pm 10.5 \mathrm{~min}(\mathrm{n}=26)$, during this process the prepupa movement displaced $42.9 \%(n=7)$ of the eggs from the original position in the cell. In two disturbed eggs, the death of the hatched protonimph was observed.

\section{Feeding behavior}

The feeding behavior of the foundress mite varied during the course of the reproductive cycle. On the prepupa the mite fed often $\left(0.6 \pm 0.2\right.$ bouts $h^{-1}, n=26$ individuals $)$ for a period of $4.5 \pm 4.6 \mathrm{~min} \mathrm{~h}^{-1}$ and there was no preference for a specific segment as a

Table 1 Reproduction parameters displayed by Varroa destructor foundress mites in artificial worker brood cells of Africanized bees

\begin{tabular}{lc}
\hline Parameter & Worker (\%) \\
\hline Fertile & 30.8 \\
Non-reproductive & 69.2 \\
Viable female offspring & 0.0 \\
Immature offspring & 25.9 \\
Females only & 3.2 \\
Males only & 3.2 \\
\hline
\end{tabular}




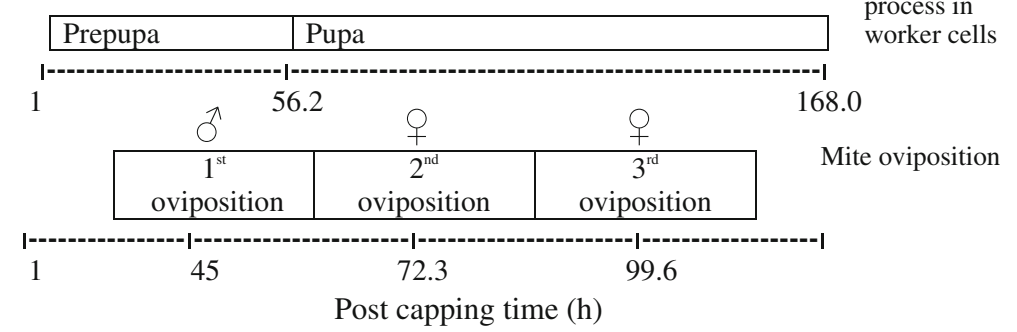

Fig. 1 Time-activity relationship between the first mite oviposition and the molting process of the bee prepupa

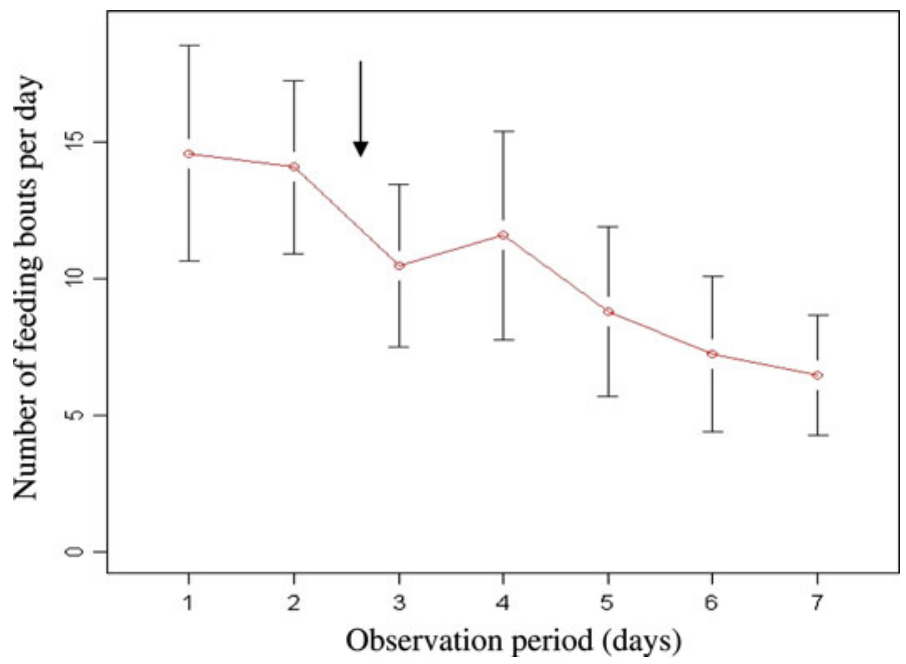

Fig. 2 Feeding bouts of varroa mites in worker brood cells of Africanized bees during a period of 7 days $(168 \mathrm{~h})($ mean $\pm \mathrm{SD})$. On the prepupa the mite fed often $(\mathrm{n}=26)$. The arrow indicates the beginning of the pupal stage $(\mathrm{n}=26)$

feeding site. The foundress mite often changed location for feeding. However, during the pupal stage the mite fed less often $\left(0.4 \pm 0.3\right.$ bouts $\mathrm{h}^{-1}, \mathrm{n}=26$ individuals $)$ for a period of $7.3 \pm 4.5 \mathrm{~min} \mathrm{~h}^{-1}$ and almost always at the same point.

There was a difference between the mean number of times the mite fed on prepupa $(14.5 \pm 6.9)$ and pupa $(9.9 \pm 6.5)(\mathrm{t}$-test, $p<0.05, d f=1$; Fig. 2$)$. On the prepupa the mite fed $108.2 \pm 109.4 \min ^{-1 a y}{ }^{-1}(\mathrm{n}=26)$, whereas on the pupa it fed $175.4 \pm$ 107.1 min day $^{-1}(\mathrm{n}=26)$ (t-test, $\left.p<0.05\right)$.

By contrast with the first short feeding bout of $4.0 \pm 3.0 \mathrm{~min}$ on the prepupa, the first feeding bout by the adult female mite on the pupa lasted $18.0 \pm 7.5 \mathrm{~min}(\mathrm{n}=26)$ (t-test, $p<0.05, d f=1)$.

In the pupal stage of worker brood, the integumental wounds were detected by a vital staining. The blue margin of the wound contrasts in particular with the white-brown skin of early pupal stages ( 7 days). Also in later pupal phases ( 8 days or more), the enlarged puncture was easy to localize as a blue spot. On pupae a high percentage of the wounds 
Table 2 Position and amount of varroa-made integumental wounds on the surface of the Africanized bee worker pupal body $(\mathrm{n}=82)$

\begin{tabular}{lr}
\hline Position and amount of wounds & $\%$ \\
\hline Abdomen & 79.3 \\
Thorax & 15.8 \\
Legs & 4.9 \\
One perforation & 98.8 \\
Two perforations & 1.2 \\
\hline
\end{tabular}

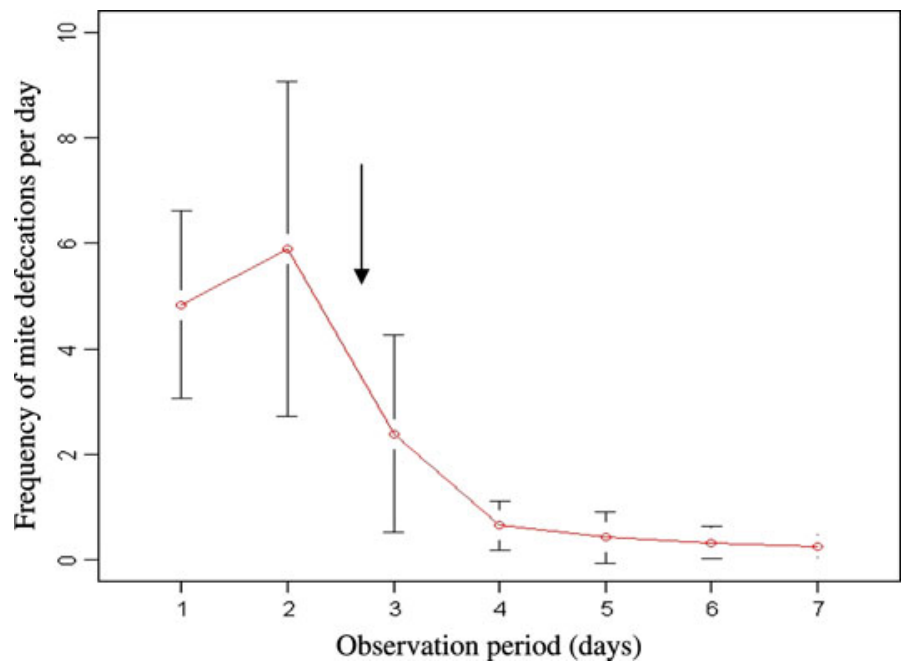

Fig. 3 Frequency of varroa defecations in worker brood of Africanized bees (mean \pm SD). During the second day the mite defecated more frequently. The arrow indicates the beginning of the pupal stage

was on the abdomen, specifically on the 2nd abdominal segment (ventral position) $(\mathrm{n}=82)$. There were no punctures on the head and few perforations were found on thorax and legs. On the majority of pupa there was only one perforation (Table 2).

Fecal accumulation

Varroa female concentrated the feces on a little spot. Fecal accumulation site formation started with the deposition of a few feces near one another. The accumulation site appears as a bright white amorphous mass that contrasts in color with the transparent cell wall to which it is attached. On the pupal stage, varroa showed a preference for defecation in the posterior part of the cell, usually close to the bee's anal zone, near the feeding site on the pupa. Only $23.7 \%(\mathrm{n}=61)$ of the mites concentrated the feces in the anterior part of the cell.

During the second day the mites defecated more frequently, 5.9 times daily $(n=26)$, decreasing to 0.3 times on the sixth and seventh day (Fig. 3). Most of the infested cells had one fecal accumulation site $(68.9 \%)$. No fecal accumulation was found in only two cells.

Behavior of varroa appeared to be in relation to the fecal accumulation (Table 3). After feeding, the mite returned to the cell wall where it stopped on the fecal accumulation site, usually to defecate. A significant association was observed between the position of the feeding point in the pupa and the defecation site on the cell wall. Varroa descends onto 
Table 3 Position of the feeding point $(n=82)$, fecal accumulation site $(n=61)$ and oviposition $(n=15)$ of varroa mites in worker brood cells

\begin{tabular}{llll}
\hline Behavior & Position in the cell & $\%$ & Statistical test \\
\hline Feeding & Medium & 15.8 & $\chi^{2}=91.0, \mathrm{df}=2, p<0.05$ \\
& Posterior & 84.2 & \\
Defecation & Anterior & 23.7 & $\chi^{2}=52.5, \mathrm{df}=2, p<0.05$ \\
& Posterior & 71.0 & \\
Oviposition & Anterior & 40.0 & $\chi^{2}=5.2, \mathrm{df}=2, p>0.05$ \\
& Posterior & 53.0 & \\
\hline
\end{tabular}

the pupa exclusively to feed. After each feeding bout, the mite swiftly returned to the cell wall where it stopped on the feces. The proximity of the fecal accumulation to the feeding site facilitates the feeding activity of the mites. In addition, more than half of the eggs were located around the fecal accumulation.

\section{Displacement behavior}

Turning movements around the cell, from the bottom to the top of the cell (displacement behavior), were clearly carried out by some bee larva. Longitudinal displacement was observed in $71.0 \%(\mathrm{n}=26)$ of the infested bee larva. The bee larva showed the displacement behavior mainly on the first day after capped $\left(31.6 \pm 18.4 \mathrm{~min} \mathrm{~h}^{-1}\right)$, with a total time of $758.4 \pm 441.8 \mathrm{~min}^{\mathrm{day}}{ }^{-1}$ ( $\mathrm{n}=18$ individuals).

The displacement movement did not affect the growth of the bee larva, because all of them completed the development into the adult stage. However, the feeding activity of the mite during the larva displacement was reduced $\left(10.9 \pm 8.2\right.$ bouts day $^{-1}, \mathrm{n}=18$ indi-

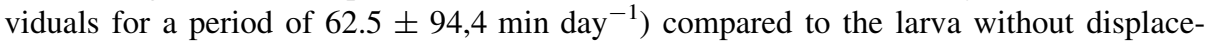
ment $\left(19.6 \pm 8.6\right.$ bouts day $^{-1}, \mathrm{n}=8$ individuals for a period of $196.4 \pm 124.0$ min day $^{-1}$ ). In addition, in two cells with larva displacement the mite started the oviposition too late (more than $100 \mathrm{~h}$ after cell capping). In the uninfested cells (analyzed for bee brood development) no displacement movement was observed.

\section{Discussion}

Observation of varroa mites behavior in capped worker brood of Africanized honey bees, contribute to the understanding of the relationship between the host and the parasite. Using this direct method, we were able to describe a significant adaptation on the part of varroa mites in parasitizing the developing bee inside the sealed cells. Furthermore, how varroa is not only confronted with the challenge of reproducing within the limited time span of bee development within the brood cell, but also with changes and limitation of available space due to bee metamorphosis.

Mite fertility in artificial worker brood cells was less than thirty-five percent. It is reported that a significant lower percentage of mites reproduce on Africanized worker brood than on brood of European bees, kept in the same regions of Brazil (Camazine 1986; Moretto et al. 1995). In this study, the oviposition site for the first egg was mainly situated in the anterior part of the cell. In addition, most of the mother mites laid the first egg before bee pupation. According to Donzé and Guerin (1997), in almost all cells, the first egg is 
laid close to the operculum. This anteriorly placed egg runs a lower risk of being jostled by the emerging pupal appendages during pupation.

Although the first egg was situated in the protection of the cell cap (mainly situated in the anterior part of the cell), we observed in transparent cells that in some cases the first egg was disturbed when the prepupa molts into a pupa. Dramatic changes to the available space due to bee metamorphosis, a factor which increases the risk of mite mortality, were detected. The first egg is generally male and when it suffer a significant damage will not have any chance to get the adult stage. We consider that the absence of the adult male determined in $15.0 \%$ of 18 to 20-day-old worker brood natural cells (pupa has a dark tan or gray appearance and some movements of the legs were observed $\geq 240 \mathrm{~h}$ post-capping) (unpublished data) could be explained by this effect.

As there is only one male per family and no reproduction occurs outside brood cells, because males do not survive outside capped brood (varroa daughter must meet with males within the cell to be fertilized), the death of the male in early stages plays a central role in explaining a decrease in the production of viable daughters in Africanized bees. A direct consequence of male mortality in worker cells results in only 0.73 viable female offspring produced per mother mite, which rises to 0.85 if both mated (viable) and non-mated females are considered from AHB in Mexico (Medina and Martin 1999). For AHB in Costa Rica, the number of viable females produced per reproductive female mite in worker cells was 0.30 . If only the foundress producing viable offspring is considered this rises to 1.44 (Calderón et al. 2007).

When mites produce daughters but no living son, the daughters mites will remain unmated in single infested cells (Boot et al. 1997). These unfertilized mites cannot mate once they have emerged from the cell and so never produce viable offspring, although they do enter cells and attempt to reproduce. The mortality suffered by the first (specifically the male) mite offspring found in AHB, is thought to contribute in part to the tolerance of these bees (Medina and Martin 1999). It is reported that in the capensis honey bee (A. $m$ capensis), low mite reproductive in cells containing pseudo-clone was mainly as a result of increased mite mortality. This was caused by male protonymphs and some mothers becoming trapped in the upper part of the cell (Martin and Kryger 2002).

On most pupae only one wound was used as feeding site. According to Donzé and Guerin (1994), the mother restricts her feeding to one site on the bee after pupation. This is remarkable in a number of aspects. The length of time invested by the mother on the feeding site suggests that opening of the wound on the pupa requires a high investment. The mite invests a lot of energy in establishing the feeding site, as it will be the only one available in the cell (Donzé et al. 1998). Since the female feeds regularly, a single feeding site located in the vicinity of the fecal accumulation is maintained. Furthermore, the limited number of wounds made by varroa may be an adaptive trait, because these perforations in the pupal cuticle are routes for microbial infection, which will eventually kill the bee (Kanbar and Engels 2004b). After feeding the mite returns to the fecal accumulation. This regulated behavior adopted by the mites in a cell, assures access to the feeding site.

There are few reports on the number of perforations made by varroa females as permanent feeding sites on worker capped brood of Africanized bees (Calderón et al. 2009). Using the staining method, the damaged cells surrounding the perforation of the mite for haemolymph meals become filled with trypan blue dye (Kanbar and Engels 2004a). In this study, most of the mites inflicted wounds on the abdomen of the pupa, specifically on the 2nd abdominal segment. On pupae many of the wounds are on the 2nd abdominal segment, indicating that the female mite has a preferred feeding site (Kanbar and Engels 2004b). 
This confirms the video records of Donzé and Guerin (1994) who, nevertheless named this abdominal segment 5, because they included the three thoracic segments. According to Kanbar and Engels (2004b), in honey bee pupae the sternite of the 2nd abdominal segment is somewhat stretched over an underlying large haemocoelic cavity. According to Calderón et al. (2009), on pupae many of the wounds were found mainly on the left side on the abdomen. On $15.8 \%$ of the pupae the wounds were located on the thorax. Kanbar and Engels (2004b) reported that $24.7 \%$ of the wounds were located on the thorax of the worker pupae. It is of significance that varroa never feeds on the head of the pupa, thus avoiding possible damage to the developing stage (Donzé and Guerin 1994).

On the pupal stage, varroa shows a preference for defecation close to the bee's anal zone. Use of the posterior region of the cell by varroa and concentration of the feces at one site could reduce any odorous emissions, a factor which may be of significance in reducing detection by the hygienic behavior of bee workers (Donzé and Guerin 1994). Hygienic behavior is related to bees opening up capped brood cells and removing the brood (Peng et al. 1987; Spivak 1996). In addition, this site position on the cell is due to the fact that varroa shows negative geotaxis when defecating (Donzé and Guerin 1994). Once the fecal accumulation has been constructed, the mite becomes progressively rigid in its behavior routine. It only leaves the fecal accumulation to feed on the bee pupa, returning to it after each feeding bout usually to defecate.

We found an association between the position of the feeding site on the pupa and the position of the fecal accumulation site on the cell wall. All of this suggests that the fecal site serves as a great time and energy saver for the parasite in its race to maximize the number of fertilized offspring before bee emergence (Donzé and Guerin 1994). In addition, most of the eggs were located around the fecal accumulation site. The male always hatches in the anterior part of the cell and has to rejoin the posterior section to access the prepared feeding site. This ensures that adult daughters and males meet to copulate (Donzé et al. 1998).

In this study with Africanized bees, an additional movement was observed in the larval stage. Longitudinal displacements around the cell were carried out by most of the analyzed larva. The feeding activity of the mites during these larval movements was reduced. In some cases the bee larva apparently moved toward the mite and pushed it against the cell wall.

The significance of the displacement behavior is not totally clear (Calderón et al. 2009). Because of bee larva apparently pushed the mite against the cell wall, it could be considered as a defense mechanism of the larva to varroa mites. There are no reports in the literature describing this type of displacement movement on capped brood. No displacement movement was observed in the uninfested cells. So far, hygienic and grooming behavior has been proposed as important resistant mechanisms of Africanized bees to varroa. Both resistance mechanisms are described only for adult bees. Therefore the displacement behavior could account for the decrease in mite reproductive success in worker brood cells of Africanized bees.

In conclusion, these results in worker brood of Africanized bees demonstrate adaptations on behalf of varroa mites in parasitizing the developing bee inside the capped brood cells and how the mite is confronted with changes to the available space due to bee metamorphosis and reduced feeding activity on the larva. Even if the first egg was situated in the anterior part of the cell, in some cases it was disturbed when the prepupa molts into a pupa. The mother mite prepares a feeding site on the bee pupa and a fecal accumulation site on the cell wall. The fecal accumulation is situated near to the feeding site on the pupa. The feeding site on the pupa was found preferentially on the sternite of the 2 nd abdominal 
segment and most pupae there was only one perforation. In cells with displacement larva, the feeding activity of the mites was reduced. In a further study, we will focus on varroa behavior in drone brood cells in AHB under these artificial conditions.

Acknowledgments We would like to thank Anton Imdorf, Swiss Bee Research Centre, Switzerland, for providing us with the artificial transparent cells and Gérard Donzé for his recommendations. Special thanks to Fernando Ramírez for the preparation of the Africanized colonies.

\section{References}

Anderson DL, Trueman JWH (2000) Varroa jacobsoni (Acari: Varroidae) is more than one species. Exp Appl Acarol 24:165-189

Bailey L, Ball BV (1991) Honey bee pathology. Academic Press, London

Boot W, Tan NQ, Dien PC, Huan LV, Dung NV, Long LT, Beetsma J (1997) Reproductive success of Varroa jacobsoni in brood of its original host, Apis cerana, in comparison to that of its new host, Apis mellifera (Hymenoptera: Apidae). Bull Entomol Res 87:119-126

Calderón RA, Sommeijer MJ, de Ruijter A, van Veen JW (2003) The reproductive ability of Varroa destructor in worker brood of Africanized and hybrid honey bees in Costa Rica. J Apic Res 42:65-67

Calderón RA, Zamora LG, Van Veen JW, Quesada MV (2007) A comparison of the reproductive ability of Varroa destructor (Mesostigmata: Varroidae) in worker and drone brood of Africanized honey bees (Apis mellifera). Exp Appl Acarol 43:25-32

Calderón RA, Fallas N, Zamora LG, Van Veen JW, Sanchez LA (2009) Behavior of varroa mites in worker brood cells of Africanized honey bees. Exp Appl Acarol 49:329-338

Camazine S (1986) Differential reproduction of the mite, Varroa jacobsoni (Mesostigmata: Varroidae), on Africanized and European honey bees (Hymenoptera: Apidae). Ann Entomol Soc Am 79:801-803

Correa-Marquez MA, Medina L, Martin S, De Jong D (2003) Comparing data on the reproduction of Varroa destructor. Genet Mol Res 2:1-6

De Jong D (1997) Varroa and other parasites of brood. In: Morse R, Flotum K (eds) Honey bee pests, predators, and diseases, 3rd edn. A. I. Root Co, Ohio, pp 280-327

Donzé G, Guerin P (1994) Behavioral attributes and parental care of varroa mites parasiting honey bee brood. Behav Ecol Sociobiol 34:305-319

Donzé G, Guerin P (1997) Time-activity budgets and spacing structure by the different life stages of Varroa jacobsoni in capped brood of the honey bee, Apis mellifera. J Insect Behav 10:371-393

Donzé G, Herrmann M, Bachofen B, Guerin P (1996) Effect of mating frequency and brood cell infestation rate on the reproductive success of the honey bee parasite Varroa jacobsoni. Ecol Entomol 21:17-26

Donzé G, Fluri P, Imdorf A (1998) A look under the cap: the reproductive behavior of Varroa in the capped brood of the honey bee. Am Bee J 138:528-533

Grandi-Hoffman G, Page R, Martin J, Fondrk K (2002) Can the frequency of reduced Varroa destructor fecundity in honey bee (Apis mellifera) pupae be increased by selection? Apidol (Celle) 33:563-570

Harris JW, Harbo JR (1999) Low sperm counts and reduced fecundity of mites in colonies of honey bee (Hymenoptera: Apidae) resistant to Varroa jacobsoni (Mesostigmata: Varroidae). J Econ Entomol 92:83-90

Kanbar G, Engels W (2004a) Visualisation by vital staining with trypan blue of wounds punctured by Varroa destructor mites in pupae of the honey bee (Apis mellifera). Apidol (Celle) 35:25-29

Kanbar G, Engels W (2004b) Number and position of wounds on honey bee (Apis mellifera) pupae infested by a single Varroa mit. Eur J Entomol 101:323-326

Martin SJ (1994) Ontogenesis of the mite Varroa jacobsoni Oud. in worker brood of the honey bee Apis mellifera L. under natural conditions. Exp Appl Acarol 18:87-100

Martin SJ, Kryger P (2002) Reproduction of Varroa destructor in South African honey bees: does cell space influence Varroa male survivorship? Apidologie 33:51-61

Martin SJ, Medina L (2004) Africanized honeybees have unique tolerance to Varroa mites. Trends Parasitol 20:112-114

Martin SJ, Holland K, Murray M (1997) Non-reproduction in the honey bee mite Varroa jacobsoni. Exp Appl Acarol 21:539-549

Medina L, Martin SJ (1999) A comparative study of Varroa jacobsoni reproduction in worker cells of honey bees (Apis mellifera) in England and Africanized bees in Yucatan, Mexico. Exp Appl Acarol 23:659-667 
Mobus B, Bruyn C (1993) The new varroa handbook. Arc \& Throstle Press, Todmorden

Mondragon L, Martin SJ, Vandame R (2006) Mortality of mite offspring: a major component of Varroa destructor resistance in a population of Africanized bees. Apidol (Celle) 37:67-74

Moretto G (1997) Defense of Africanized bee workers against the mite Varroa jacobsoni in Southern Brazil. Am Bee J 137:746-747

Moretto G, Leonidas J (2001) Infestation and distribution of the mite Varroa jacobsoni in Africanized honey bees (Apis mellifera) colonies. Interciencia 26:393-396

Moretto G, Leonidas J (2003) Infestation and distribution of the mite Varroa destructor in colonies of Africanized bees. Braz J Biol 63:83-86

Moretto G, Pillati A, De Jong D, Goncalves L, Cassini F (1995) Reduction of varroa infestations in the state of Santa Catarina, in Southern Brazil. Am Bee J 135:498-500

Peng YS, Fang Y, Xu S, Ge L (1987) The resistance mechanism of the Asian honey bee Apis cerana Fabr. to an ectoparasitic mite. Varroa jacobsoni Oudemans. J Invertebr Pathol 49:54-60

Ritter W, De Jong D (1984) Reproduction of Varroa jacobsoni O. in Europe, the middle East and tropical South America. Z Ang Entomol 98:55-57

Spivak M (1996) Honey bee hygienic behavior and defense against Varroa jacobsoni. Apidologie $27: 245-260$ 